\title{
Dateline Orange City, Iowa: De Volksvriend and the Creation of Dutch American Community in the Midwest, 1874-1951
}

\author{
ROBERT SCHOONE-JONGEN
}

EACH WEEK FOR 77 YEARS De Volksvriend appeared in thousands of Dutch American homes. From its base in Orange City, Iowa, "The People's Friend" created a community of readers reaching from coast to coast and beyond, from border to border and beyond. For most of its existence this weekly newspaper provided eight pages of news in words the immigrants understood, information about their new nation and their old home country. The editors regaled their readers with a mixture of national political events, wars from around the world, serialized novels, church news, and natural disasters. Republican to the bone (at least until the Great Depression came in the 1930s) and Reformed to the core, De Volksvriend was reliable and safe.

While the editors viewed the world from the vantage point of northwestern Iowa, the columns of submissions (correspondentie in Dutch) from dozens of datelines, which occupied as much as a third of the space in some issues, enabled the paper to reach beyond a purely local audience. From places as far from each other as Bradenton, Florida, and Lynden, Washington, or Whitinsville, Massachusetts, and Bellflower, California, and hundreds of places in between, dozens of self-appointed Dutch correspondents reported to other Dutch immigrants

THE ANNALS OF IOWA 69 (Summer 2010). (C) The State Historical Society of Iowa, 2010. 
what was happening to still other Dutch immigrants in at least 27 states and 5 Canadian provinces. Some locales appeared in each issue, others less frequently. Some never stopped appearing while others disappeared with the death of a faithful correspondent. The newspaper's editors and publisher came to understand the vital importance these chatty missives held for the readership. One editor's son, noting that even he read all of the correspondence regularly, observed that, "at least in my father's judgment, his newspaper could fill the role of holding the Dutch people together as an ethnic identity." ${ }^{1}$

Benedict Anderson's influential book Imagined Communities opens with the observation that a nation "is imagined because the members of even the smallest nation will never know most of their fellow-members, meet them, or even hear of them, yet in the minds of each lives the image of their communities." ${ }^{2}$ Ethnic communities in the United States conformed to this observation as they scattered from one end of the country to the other. Ethnic groups distinguished themselves from each other, often espousing the superiority of their particular culture. Where enough members of the group came to reside in a locale, that place became one of "our towns" inhabited by "our people" - a safe haven in the surrounding ocean of difference - and De Volksvriend's correspondence columns catalogued their existence and formed a public communications network among them. ${ }^{3}$

1. D. Ivan Dykstra, "B.D.": A Biography of My Father, the Late Reverend B. D. Dykstra (Grand Rapids, MI, 1982), 125.

2. Benedict Anderson, Imagined Communities: Reflections on the Origin and Spread of Nationalism (New York, 2000), 5-7.

3. Other newspapers also catered to Dutch American communities; they were published in Wisconsin, Illinois, Michigan, and New Jersey, as well as in Pella, Iowa. But De Volksvriend had a larger circulation and endured longer than the others. Several "Dutch" settlements in the upper Midwest included Ostfrisians who originated from the area along the Dutch-Hanover border and often affiliated with the same Calvinist denominations to which the Dutch gravitated. Ostfriesische Nachtrichten was published in Breda, Iowa. Henry S. Lucas, Netherlanders in America: Dutch Immigration to the United States and Canada, 1789-1950 (Grand Rapids, MI, 1989), 529-41; Jacob Van Hinte, Netherlanders in America: A Study of Emigration and Settlement in the Nineteenth and Twentieth Centuries in the United States of America (Grand Rapids, MI, 1985), 445-62, 914-41; George Schnucker, The East Frisians in America, trans. Kenneth De Wall (Bethalto, IL, 1985), 273-79; Matthew Lindaman, "Heimat in the Heartland: The Significance of an Ethnic Newspaper," Journal of American Ethnic History 23 (2004), 78-98. 
DE VOLKSVRIEND began as a publicity piece to promote the real estate interests of its first publisher and editor, Henry Hospers. He was by turns a surveyor, banker, promoter, entrepreneur, civic booster, public official, and lay leader in the church. And he could write. He had been present at the creation of Hendrik Scholte's Dutch colony at Pella, Iowa, in 1847. Then, in 1870, Hospers migrated across the prairie to Iowa's northwestern corner to found another settlement in Sioux County. He recruited colonists from Dutch communities in Iowa, Michigan, Illinois, and Wisconsin. With the blessing of the state's immigration board, he traveled to the Netherlands in search of still more pioneers. He was also a hands-on politician who, in one of Iowa's most notorious county sear wars, led the Dutch expedition that commandeered Sioux County's records and safe from "degenerate" Calliope to "virtuous" Orange City during January 1871.

Hospers learned the newspaper business in Pella, where he edited and published the Pella Weekblad from 1861 until he prepared to move to Sioux County in 1870 . He began publishing De Volksvriend in Orange City on June 18, 1874, announcing to his 120 subscribers that the new weekly would inform "our fellow-Hollanders [about] a magnificent spot of God's earth where there is plenty of opportunity ... for many a Dutch household, where the Lord out of His grace ... has shown He is well pleased, where there is abundant opportunity to train the rising generation." ${ }^{5}$ The settlement's subsequent growth and endurance confirmed his claims. De Volksvriend functioned as much like a real estate infomercial as it was a newspaper, intending "to make the facts known far and wide, to attract the attention of emigrants to our colony." Already looking beyond the immediate area, Hospers hoped that "others shall write articles, and we hope our fellow-colonists will help us spread De Volksvriend." ${ }^{\prime 6}$ In the

4. Van Hinte, Netherlanders in America, 485-89.

5. Quoted in Jacob Van der Zee, The Hollanders of Iowa (Iowa City, 1912), 252.

6. Ibid., 253-54. Hospers also showed his free enterprise side by telling potential emigrants in the Netherlands that they need not worry about being short on cash, because "if you have children, they are the best capital you can bring to America." For early examples of Hospers's views on America and his appeals for fellow Netherlanders to come to Iowa, see Johan Stellingwerf, comp., Iowa Letters: Dutch Immigrants on the American Frontier, ed. Robert P. Swierenga and trans. Walter P. Lagerwey (Grand Rapids, MI, 2004), 115-218. 
early years this cosmopolitan vision remained limited to paragraphs lifted from the most recent issue of the Pella paper.

Henry Hospers used his influence as a Sioux County commissioner to secure the right to publish Dutch translations of official notices. These columns of minutes, land transactions, election results, and auction bills ensured the paper's financial viability and gave a potential audience a reason to purchase subscriptions. When Hospers won a seat in the state legislature in 1886, he added Dutch translations of gubernatorial proclamations as another source of revenue for his newspaper. But county or township road contracts and jury lists would not long hold the interest of readers hundreds of miles away from Orange City.

With his civic duties and business interests growing, in 1881 Henry Hospers hired Kasper Tietema to edit De Volksvriend. Over the next four years Tietema gradually shifted the paper's focus to reflect changing settlement patterns in the upper Midwest. With the Dutch already occupying large tracts of the arable land in Iowa's extreme northwestern corner, a secondary wave of settlements formed to the north, west, and southwest, in places such as New Holland, Hull, and Thule in Dakota Territory; Holland and Prinsburg in Minnesota; and Prairie View and Luctor in Kansas. Along with other Orange City investors, Hospers dabbled in several of these new locales, lending starting capital, investing some of his own funds in undeveloped land, and even publishing Dutch and English newspapers in Dakota. ${ }^{7}$ Editor Tietema added clippings from Hospers's Dakota papers to the Pella news regularly printed in De Volksvriend. "Dakota News" combined ordinary rural fare (weather and crop reports) with booster-ish social news ("J. A. Brink's move here from Sioux County went well"). ${ }^{8}$ Then in 1884 Tietema

7. Hospers purchased the north half of section 1 in Osborne Township, Pipestone County, Minnesota, on December 4, 1890, and 80 acres in Burke Township on July 10, 1891. Contracts 2228, 2229, and 2434, Close Brothers \& Co. land contract files, Pipestone County Historical Society, Pipestone, Minnesota. Another Orange City investor, William Rieckhoff, purchased tracts in Leota Township, Nobles County, Minnesota. Contracts 2164-65 and 2201-4, ibid. Those tracts were located in the southwestern corner of the state, the site of the second-largest Dutch American colony in Minnesota.

8. De Volksvriend, 7/3/1884, 7/3/1890. In 1884 Henry Hospers began to publish De Hollandsche Dakotiaan. His son Jan served as its editor. The newspaper 
published a notice that he would welcome submissions from self-appointed correspondents who wanted to keep their fellow Dutch Americans informed about events in the new settlements.

Tietema personally modeled this more expansive view by traveling to one of the Minnesota colonies during the summer of 1885 and subsequently reporting his findings in a series of articles. In addition, Pieter Haan, a Dutch American real estate salesman who until recently had lived in Orange City, began submitting accounts of his activities in central Minnesota. By turns as letters to the editor, advertisements, or news items, Haan's stories described the arrival of prospective and actual settlers in the Prinsburg colony. ${ }^{9}$ Haan's dispatches were the prototype for a collection of thousands of articles that became the heart and soul of De Volksvriend until its demise at the end of 1951.

FROM 1884 UNTIL 1891, the articles from the Dutch frontiers appeared in a rather haphazard fashion. Frequency and placement in the paper varied. There were no distinctions between opinion pieces, religious jeremiads, protest letters, and more conventional news accounts. The varying frequency of the correspondence reflected the vagaries of life on the Great Plains during the period. Mail service, particularly during the winter months, could be erratic. Some of the new settlements, such as Prinsburg, were located miles from the nearest railroad line. Just getting to them was often a challenge. And life in a crude, new place was not conducive to composing polished prose.

In 1885, when Kasper Tietema heard the call to take up the cloth and departed for a Presbyterian seminary, Hospers turned to Antonie J. Betten Jr. to be the next editor of De Volksvriend. ${ }^{10}$

endured for only about two years. In addition, the Harrison Globe briefly included a Dutch language section that was also edited by Jan Hospers until 1887, when he began publishing De Harrison Bode, which ceased publication in the early 1890s. Lucas, Netherlanders, 536-37.

9. De Volksvriend, 1/8/1885,3/26/1885, 7/9/1885.

10. Tietema was ordained as a Presbyterian minister in 1891 . He accepted a call to a Dutch Presbyterian congregation in Fillmore County, Minnesota. While serving that church, he also served as De Volksvriend's correspondent for the hamlet of Greenleafton, Minnesota. 
The son of a notable local minister, Betten was Sioux County's treasurer and Orange City's mayor and a close friend and political ally of Hospers. At the age of 46 Betten settled into the editor's chair at De Volksvriend. Under his direction the paper expanded to eight pages, with religious news filling much of the additional space. The paper highlighted events and issues of particular interest to members of the Reformed Church in America. Lengthy accounts of church meetings appeared with increasing regularity. In addition, the paper devoted many columns to writers who believed that missionary activities around the world proved that the end of the world was near at hand. ${ }^{11}$

Although the editorial bent shifted, the newspaper's physical appearance did not change during Betten's six-year tenure. As was common with small weekly newspapers of the period, advertisements swarmed over every page, some in the style of business cards, others as want ads and box ads. They framed local news, legal notices, news from the Netherlands and the United States, church matters, and lengthy essays on doctrinal issues, many of them written either by Betten's own father or by like-minded ministers or laymen who lived at a distance. Local news from northwestern Iowa remained a basic ingredient, reflecting who the readers generally were.

In 1891 Henry P. Oggel purchased De Volksvriend from Henry Hospers, after Antonie J. Betten quit as editor to manage the general store he owned in Orange City. Oggel and Hospers had known each other in Pella, where Oggel had been a physician with informal credentials. During the 1880s Oggel moved to Orange City to ply his skills. In 1887 he joined the faculty of the local classical academy to teach modern languages and physiology. ${ }^{12}$ He ultimately found his true calling in the newspaper office located several blocks up Central Avenue from the academy.

11. Betten's father (Antonie Sr.) was one of the most frequent of those contributors. Earl Wm. Kennedy, "Prairie Premillennialism: Dutch Calvinist Chiliasm in Iowa, 1847-1900, or the Long Shadow of Hendrik Pieter Scholte," Reformed Review 46 (1992), 153-67. See also idem, “A. J. Betten: The Other Pioneer Pella Dominie," in The Sesquicentennial of Dutch Immigration: 150 Years of Ethnic Heritage, ed. Robert P. Swierenga and Larry Wagenaar (Holland, MI, 1998), 97-112.

12. Gerald F. DeJong, From Strength to Strength: A History of Northwestern, 18821982 (Grand Rapids, MI, 1982), 40. Henry Hospers was a major force behind 
Henry Oggel looked for readers in the rapidly expanding network of Dutch American enclaves that stretched from Wisconsin and Minnesota westward to Montana, Colorado, Washington, and California. Many residents of those enclaves had family ties to northwestern Iowa, having moved west from there beginning in the 1880s. As Kasper Tietema had before him, the new editor printed articles from his readers. Those contributors received free subscriptions and acted as local sales agents. ${ }^{13}$ Their efforts produced a dramatic increase in subscribers, and presumably revenue. Oggel inherited a subscription list of approximately 1,000 names. Within four years he doubled that number. By 1909 the list had doubled again, to $4,000 .^{14}$

THE WEEKLY ROUND of correspondence articles gradually grew into the core of each issue of De Volksvriend. Amid the columns of church news, theological commentaries, patent medicine advertisements, and legal notices, "Correspondence," according to at least some readers, became the paper's most read segment. ${ }^{15}$ The fluctuation in the numbers of these articles at regular intervals illustrates the growth and decline of the newspaper's readership, interests, and ethnic identity. ${ }^{16}$

During the first four months of 1891, 28 articles from nine locations appeared. Only Pella, Iowa, appeared in every issue.

the establishment of the Northwestern Classical Academy: he donated the land upon which the school stood and served on its board of trustees.

13. The correspondents clearly knew who the subscribers were in their area and often concluded their dispatches with phrases such as, "one new subscriber," or "two new subscribers," or "one new subscriber, a friend of the farmers." De Volksvriend, 4/2/1896, 12/8/1899, 12/28/1899, 3/8/1901, 3/21/ 1901; Dykstra, "B.D.," 125.

14. Lucas, Netherlanders, 536.

15. Dykstra, "B.D.," 125 . There is anecdotal evidence of this among those who remember reading the paper on a regular basis. The author was acquainted with many of them who resided in Edgerton, Minnesota, several decades after the paper's demise.

16. In each instance the sample involves tabulating the sources of the articles during the first four months of the years 1891-1951 taken at five-year intervals. The sample begins with H. P. Oggel's first year as editor and ends with the newspaper's final year of publication. The sample does not include every correspondent or locale, but it does suggest the newspaper's reach and history. 
FIGURE 1

Number of Correspondence Articles in De Volksvriend (1891-1951)

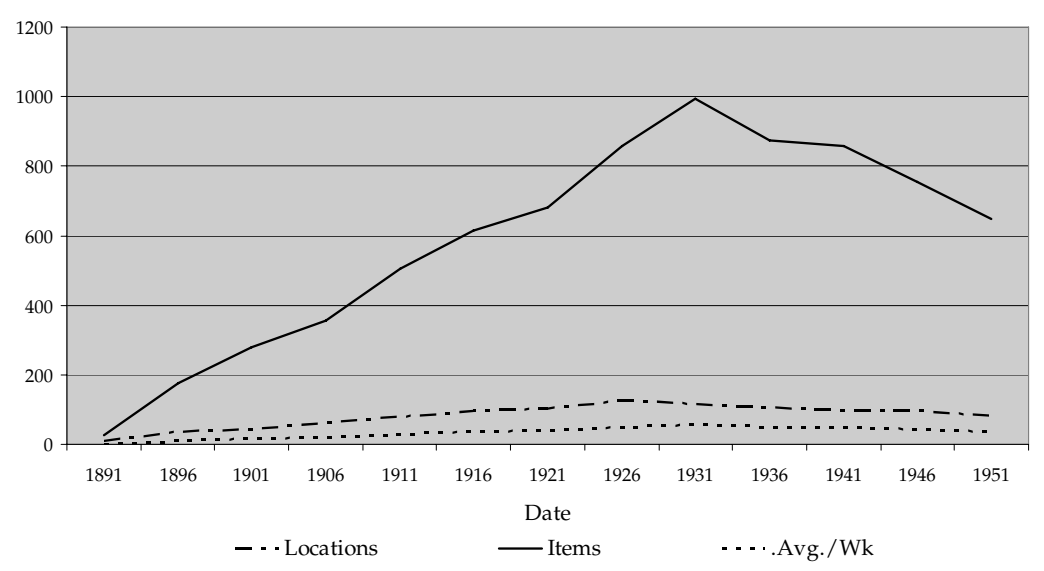

The only other multiple appearances were Harrison, South Dakota (where Hospers owned the local newspaper), and Hull, Emmons County, North Dakota. From that modest start the volume steadily increased. By four years later the numbers had increased to 176 articles from 36 locations. Pella remained the most consistent source, and Harrison, South Dakota, made almost weekly appearances. But the shape of the future also appeared in the form of two tiny Wisconsin Dutch American colonies, Alto in Fond du Lac County and Baldwin in St. Croix County. Both were among the least of Wisconsin's whistle stop towns, but they loomed large in De Volksvriend's Dutch American firmament and would remain so for much of the newspaper's remaining history. During the opening months of 1896 Alto's correspondent submitted 12 articles; Baldwin's sent in 14.

The growth of the newspaper's "Correspondence" articles continued for the ensuing 35 years, reaching a peak in 1931 (fig. 1). During the four-month periods of the sample, 956 articles appeared from 118 different addresses. Several sources came and went with the rise and decline of some settlements, the deaths of correspondents, or simple loss of interest in continuing contact with distant, and increasingly unfamiliar, audiences throughout the United States. The geographical spread of the cor- 
FIGURE 2

Regional Distribution of Correspondence Articles in De Volksvriend (1891-1951)

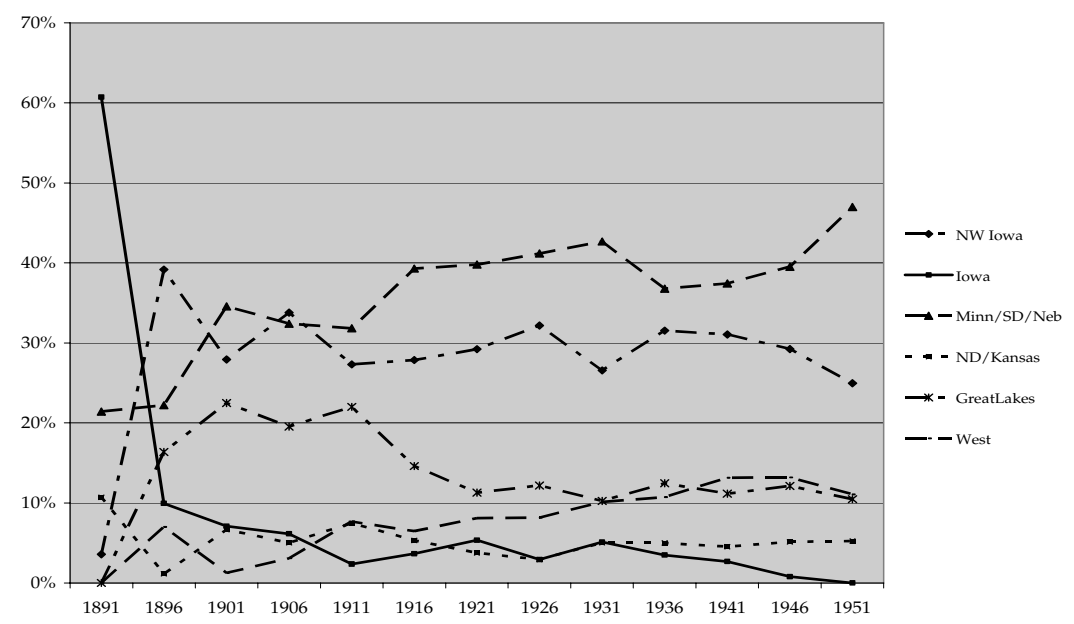

respondents reflected the ongoing dispersion of Dutch American colonies. Although the newspaper was published in northwestern Iowa and increasingly relied on local advertisers for financial support, that region had quickly fallen into second place as a source for the articles. A band of settlements that stretched from Bejou, Minnesota, in the north to Lancaster County, Nebraska, in the south provided almost 43 percent of the articles. Baldwin, Wisconsin, still appeared most weeks, but Alto's address had been replaced by neighboring Brandon when that village became the site of the local post office (fig. 2).

After 1900, the "Correspondence" spread beyond the inside pages of the paper. Some moved to the back page, especially in issues with a particularly large number of lengthy contributions. But even more tellingly, the bottom corners of the front page became home to correspondence headlined either "From Other States" or "From Wisconsin" or another particular state. By the 1920s these columns sometimes read "From California." As Dutch American settlements along the West Coast, from Lynden, Washington, to the outskirts of Los Angeles, matured, 
news items from them came to account for 10 percent of the submitted news in the paper. By 1941 the trend peaked at 13 percent. During that year's sample period, news from Bellflower, California, appeared in all but one issue.

THE REMARKABLE LOYALTY the correspondents displayed spoke of a profound sense of connectedness and community created via De Volksvriend. The correspondents formed a who's who of literary aspirants and local promoters, selfappointed ambassadors for their adopted homes whose preference for tinted lenses tended toward shades of rose and pink. In 1901 the Greenleafton, Minnesota, correspondent was none other than Kasper Tietema, De Volksvriend's former editor, now a minister in the Presbyterian church. Reinder E. Werkman promoted his real estate interests in the Pacific Northwest via news items from Seattle. Later he reported from settlements in Montana and Minnesota. H. Oordt wrote that Oregon was a great place for dairy farmers, where the butter was "as good as in Friesland." He also noted that hunters were killing four to five bears or deer per day. "Young Dutchmen, come on out here. And if you lack capital make a living [here] as a shoemaker, etc." ${ }^{18}$ Werkman may have been a mercenary looking for prospective clients, but most of the correspondents seem to have been ordinary folks who used the pages of the De Volksvriend as a surrogate backyard fence, a place to swap stories, gossip, recipes, and opinions.

For almost 30 years Klaas Gerben Feyma from Sandstone, Minnesota, was one of those faithful contributors. His columns can help illumine his experience as an immigrant and the attraction the "Correspondence" features held for the newspaper's readers. ${ }^{19}$ Feyma primarily served as a correspondent, first for

18. De Volksvriend, 1/17/1892, 7/4/1895, 1/3/1895.

19. For more detailed accounts of Feyma's life and writings, see Robert P. Schoone-Jongen, "Klaas G. Feyma: Friesland, Minnesota's Carpenter/Correspondent," in The Dutch Adapting in North America: Papers Presented at the Thirteenth Biennial Conference for the Association for the Advancement of DutchAmerican Studies, ed. Richard H. Harms (Grand Rapids, MI, 2001), 44-49; and idem, "A Time to Gather, a Time to Scatter: Dutch American Settlement in Minnesota (1885-1910)" (Ph.D. diss., University of Delaware, 2007), 118-20, 217-19. 
Friesland, Minnesota, and then for nearby Sandstone. He also contributed stories and apocalyptic commentaries on current events. ${ }^{20}$ His story emerges from an occasional sentence or paragraph in his articles. ${ }^{21}$ These scattered bits and pieces provide at least a sketch of who the contributors were and how they joined De Volksvriend's editors to create an "imagined community" that stretched far beyond Orange City to embrace Dutch enclaves throughout North America. ${ }^{22}$

Klaas Feyma earned his living as a carpenter and cabinetmaker. He was born in Holwerd, Friesland, the Netherlands, in 1849, attended elementary school, learned his trade, joined the Dutch Reformed church, married, and attempted to earn a living in very difficult economic conditions. ${ }^{23}$ At age 35 he emigrated to the United States with his wife and three children. They settled first in Clymer, New York, where "one summer [I] worked with the farmers during harvest; it was impossible to handle the bundles of oats and barley behind the reaper without bloodying ones hands from grabbing Canada thistles." ${ }^{24}$ In 1886 he moved to Dresbach, Minnesota, on the Mississippi River,

20. Feyma's stories included "The Talking Clock," De Volksvriend, 11/10/1927; "Besides Joe Whitebread," ibid., 7/27/1922; "Emmanuel Wicheren and His Reform School," ibid., 5/1/1919; "Honor Your Mother and Father," ibid., 11/1/1917.

\section{De Volksvriend, 4/5/1928; Pine County Courier, 3/22/1928.}

22. Susan Olzak and Elizabeth West, "Ethnic Conflict and the Rise and Fall of Ethnic Newspapers," American Sociological Review 56 (1991), 458-74; Samuel L. Baily, "The Role of Two Newspapers in the Assimilation of Italians in Buenos Aires and Sao Paulo, 1893-1913," International Migration Review 12 (1978), 32140; Peter Conolly-Smith, Translating America: An Immigrant Press Visualizes American Popular Culture, 1895-1918 (Washington, DC, 2004). These three studies describe how ethnic newspapers served as forums in which their readers gradually answered their questions regarding who they were, how they fit into their new surroundings, and how they should deal with the tensions inherent in the immigrant experience. Baily's article is especially useful as a reminder that this process was not an exclusively American phenomenon. On the interplay of print media, religion, and social organizations in forming an ethnic identity, see Dag A. Blanck, "Constructing an Ethnic Identity: The Case of the Swedish-Americans," in Immigration and Ethnicity: American Society "Melting Pot" or "Salad Bowl"? ed. Michael D'Innocenzo and Josef P. Sirefman (Westport, CT, 1992), 25-34.

23. Annemieke Galema, Frisians to America, 1880-1914: With the Baggage of the Fatherland (Groningen, 1996), 43-66.

24. De Volksvriend, 1/21/1915. 
where a group of his in-laws lived near the Dutch enclave of New Amsterdam, Wisconsin. ${ }^{25}$

In January 1896 Feyma responded to advertisements in De Volksvriend promoting Friesland, Minnesota, a new Dutch settlement located midway between the Twin Cities and Duluth. With a down payment borrowed from the promoter, Feyma hoped to finance his farm by building houses and barns for other settlers in the colony. In five years he lost his farm, built a house for his family in nearby Sandstone, and became a fulltime cabinetmaker and furniture repairman. By then he was also a single parent raising the children his wife had borne before succumbing to complications from the delivery of their seventh child. ${ }^{26}$

Though life in Friesland, Minnesota, proved harsh and tragic for him, Feyma quickly developed an attachment to the place that bespoke sentimentality and nostalgia. His non-Dutch neighbors may well have considered him a bit dense, given his inability to prosper in America. Not only was his purse generally empty, but his English syntax was equally meager even after more than a decade in the country. In a letter pleading for mercy from the railroad company that held the mortgage to his farm, Feyma wrote, "Mijn two boys are worken on the new road West of Miller and the let the half of the pay next stand on the land." ${ }^{27}$

Whatever his English skills, Feyma could hold his own in Dutch. From his first dispatch in 1900 to the final one written only days before his death in 1928, he took up his pen to defend his home area from detractors, compare Pine County to locations in the United States and the Netherlands with which his readers were familiar, forge personal links among his fellow immigrants, mark the passing of his generation, and repeatedly express his incurable optimism. Like modern-day bloggers, correspondents such as Feyma combined observation with the

25. In his later years, Feyma often traveled from Sandstone to Dresbach to visit these relatives. As an example of how Klaas's story unfolded in his articles, his first printed reference to the death of his son John, a soldier in the American Expeditionary Force and victim of the flu epidemic of 1918, appeared in an article about one of these train trips. De Volksvriend, 9/11/1919.

26. De Volksvriend, 5/1/1902,1/21/1915.

27. Klaas G. Feyma to Hopewell Clarke, 12/12/1898, Northern Pacific Railroad Collection, Minnesota Historical Society, St. Paul, Minnesota; Contract 4743, ibid. 
parry and thrust of debate through the musings they submitted to De Volksvriend each week.

The July 19, 1900, edition of De Volksvriend included an article from the correspondent in Hagerty, Iowa. Several of his acquaintances had visited Friesland, Minnesota, in search of cheap farmland. "At first rumor had it that they were so impressed" that one of the visitors had purchased an entire section of land, and another 200 acres. Upon close inspection, however, "it all fell apart. It appears, as we hear it, that there are more woods and stones there [in Friesland] than anything else; and the folks who are there admit that there's only one Iowa." One week later, Feyma responded to these accusations. His first signed article extolled Friesland's abundant firewood, absence of searing winds, abundant potato crops, income potential, and verdant hayfields. Deliberately mimicking the accuser's conclusion, Feyma had opened his defense with, "For myself there is but one Minnesota." He ended with, "I say for myself there is only one Friesland." 28

For almost three decades Feyma scoured the pages of the paper looking for claims to counter. Any disparaging remark about Pine County earned his rebuke. He often sparred with the correspondent from Maple Lake, Minnesota. Located 100 miles to the southwest, that enclave and its Reformed church qualified as a near neighbor in the Dutch American context. Relatives from Maple Lake routinely traveled to Sandstone to visit. Courtships were common among the young people of the two communities. Families would relocate from one community to the other. The two colonies were rivals. When the Maple Lake correspondent wrote that Sandstone "took people from other colonies," Feyma responded that people had been freely moving about the earth since the days of Abraham. Intelligent people settled in the best places. If someone prayed, "Lord! What would you have me do?" and Sandstone then seemed a preferable place, who was the Maple Lake correspondent to question that settler's choice? ${ }^{29}$

28. De Volksvriend, 7/19/1900 (emphasis added), 7/26/1900.

29. De Volksvriend, 10/16/1919. This particular exchange began during September and went back and forth for about two months. A few years earlier, in another exchange with this correspondent, Feyma was less magnanimous 
One of the underlying factors in these exchanges was the fear that isolation meant a loss of ethnic identity. In the wake of the Sandstone-Maple Lake exchange, the correspondent from Ocheyedan, Iowa, wrote about a neighbor who had moved to Sandstone for a few years, only to return to Iowa "in a freight car that was emptier than when he had left." He had observed that the "young ladies are marrying Swedes or other nationalities" and that Sandstone's Dutch congregation had not grown in 11 years. "I would rather have stayed in the Netherlands than to have wasted my days there." The correspondent's final assessment was: "In isolation there are no choices, there is no Dutch colony, and none will ever develop." ${ }^{30}$

To this Feyma responded, "You used to live here. . . . Is this your thanks for that ... ? We expected better from you." He addressed the ethnicity question as an American: "Daughters do marry Swedish and German boys. There are cases of that [here]. But do the Swedes have a different Lord Jesus than we, and are they not as good as a Hollander in Heaven? I know many who are true Christians. The Hollanders are not the only good people." The church "thrives." And Feyma turned the Ocheyedan correspondent's comments about his own area against him. "As I read your reports, you complain stones and bones about your situation . . . ; about the poor mail service, the poor roads, the poor business climate ... shortages ... [of building materials and labor] ... and a poor potato crop.'

Most of Feyma's exchanges and comparisons were more positive than these examples. He bantered with the correspondent from Port Arthur, Texas, Sam Bandsma. ${ }^{32}$ An immigrant

about the rival settlement. After extolling Sandstone's strengths, he concluded, "I cannot name all the blessings that we have that Maple Lake will never enjoy." De Volksvriend, 5/28/1914.

30. Ibid., 10/23/1919.

31. Ibid., 11/6/1919. Feyma concluded, "I wish you God's richest blessings and fellowship."

32. Sam Bandsma was born in Holwerd, the Netherlands, in 1882 and emigrated to the United States in 1904. He lived in Wisconsin for about ten years before relocating to Jefferson County, Texas, drawn there by the same real estate dealer, Theodore F. Koch, who had lured Feyma to Pine County in 1896. He died in nearby Harris County, Texas, in 1965. De Volksvriend, 7/10/1919; http:/ / search.ancestry.com/cgi-bin/sse.dll?gl=allgs\&rank=0\&gsfn=sam\&gsln= 
from the Netherlands, and about five years younger than Feyma, Bandsma was, by turns, a dairy farmer and scavenger for the city of Port Arthur. The two of them compared notes on the weather, crops, and the relative merits of the climates of Texas and Minnesota. When Bandsma reported on ripe strawberries and new potatoes in March, Feyma replied, "We would be happy to hear news about Texas again from S. Bandsma." Feyma expressed concern for the lack of Dutch churches in Port Arthur. Bandsma responded that his soul was well taken care of by local pastors. ${ }^{33}$

During the 1920s these exchanges extended farther west. Feyma exchanged comments with Henry Vervoorn of Ventura, California, an immigrant from the Netherlands who had arrived in the United States in about 1904. He had lived in northwestern Iowa before heading out to California. Once established in Ventura, Vervoorn began sending news to De Volksvriend. Feyma became captivated by Vervoorn's descriptions of Elysian winters, perpetual fruit, and balmy summers on the outskirts of Los Angeles. When Feyma appeared somewhat skeptical of these claims, Vervoorn sent a crate of flowers and fruits that arrived in Sandstone during the dead of winter. The sight convinced Feyma that maybe there really was something to Vervoorn's claims. He even urged other skeptics to stop by his home to see that trees really could bloom in winter. ${ }^{34}$

These connections helped maintain a sense of community among the immigrants, even in the face of the differing cultural directions that life in the United States drove them. Not only did De Volksvriend create an imagined community, it could also help create real ones. In September 1923 Klaas's son Jacob headed west to settle in Ventura, next door to Vervoorn. Soon Klaas's youngest son also moved to Ventura. Just before Christmas 1925, Klaas boarded a train to spend the winter in California with his sons. He wrote to De Volksvriend, "We had Christmas dinner outside the house, under the tall oak tree. . . . It astonished me to be sitting there in the shade of the great oak ... in

bandsma\&gs1co $=1 \% 2 \mathrm{cAll}+$ Countries\&gs $1 \mathrm{pl}=1 \& \mathrm{sbo}=0 \& \mathrm{ufr}=0 \& \mathrm{wp}=4 \% 3 \mathrm{~b} \_8000$ 0002\%3b_80000003\&srchb=r\&prox=1\&ti=0\&ti.si=0\&gss=angs $-\mathrm{d}$.

33. De Volksvriend, 12/19/1918, 2/13/1919, 5/8/1919, 4/24/1919, 7/10/1919, $4 / 1 / 1920$.

34. De Volksvriend, 1/5/1922. 
the middle of winter. . . How great is the Lord!" When Feyma returned home to Sandstone in late May, he concluded his reports to De Volksvriend with an echo of the phrase that had ended his first defense of Sandstone, "Well friends, there is no better land in the world than California." ${ }^{35}$

Beyond encouraging moves and travel, the "Correspondence" articles fostered emotional ties that also promoted communal concern when disasters struck one of the Dutch American communities. When a tornado destroyed an uninsured barn on the farm of "our fellow countryman" Adolph Kalk, Feyma reminded his readers, "Many little contributions make a large one. ... These folks are very poor and very much need your help." Those who had been spared such calamities needed to express their thanks by helping victims, since "the Lord loves a cheerful giver. . . . Let us, as Hollanders, make Adolph Kalk joyful once again." Feyma's readers responded generously. ${ }^{36}$

Funerals also occasioned Feyma's expressions of community, which were laced with pious sentiments and admonitions to the living. When the "angel of death came and claimed" 46-year-old Gosse Straatsma, a deacon in the Sandstone Reformed Church, Feyma concluded his report with the familiar refrain, "May the Lord speak through this shocking event not just in the tears but as a reminder to us that now is the acceptable time, today is the day of salvation." Beyond the sermonizing, such stories were also intended for audiences in locations where the deceased had once resided. When Dick Vork died in Sandstone, Feyma's account mentioned Vork's connections to three different settlements, including his birthplace (Holland, Michigan) and the places where two of his children were living (Maple Lake, Minnesota, and Big Timber, Montana). At times these articles simply recounted his personal situation, most notably the lengthy article on the ceremonies that surrounded the burial of his son John Feyma, who died in the war in France on November 28, 1918.

35. De Volksvriend, 9/20/1923, 2/26/1925, 1/14/1925, 5/27/1926. Jacob Feyma's brother-in-law, Harold Vork, joined him in the move from Sandstone to Ventura.

36. Ibid., 7/5/1923, 8/23/1923. Similarly, when a Dutch American family in Hotchkiss, Colorado, lost their house in a fire, 11 individuals from Iowa, South Dakota, and Washington State sent money to help the family rebuild their home. Ibid., 4/1/1920. 
He compared the return of his son's body to the instruction Joseph had given to the Israelites "that his bones should be returned to Canaan, the land of his birth." He wrote about deaths of old friends in the Netherlands, and he commented on the passing of old friends living elsewhere in the United States. Geert Nieken had been one of the early settlers in Friesland, Minnesota. In 1912 he had moved to Orange City, the home of his second wife. There was a memorial service in Sandstone when Nieken's body was brought there for burial. Feyma used his news article to say farewell to this one-time merchant seaman who had sung Dutch psalms to his shipmates, but had now "reached the safe harbor of rest." ${ }^{37}$

This concluding comment encapsulated the final motive behind Feyma's articles: to help his fellow Dutch Americans see the good that surrounded them. He was an inveterate optimist. Given the harrowing experience of immigration, the very lean years living in upstate New York, his meager circumstance in Dresbach, his failed farm in Minnesota, the death of his wife at a young age, his struggles to raise his children as a single parent, the death of his son in France, the stagnation of the Dutch American colony in which he resided - despite all of this Feyma was a happy person. And he tried to cultivate a spirit of mutuality in his readers. To him, America was a good place, even better than the Netherlands. He offered recipes for chicken feed and hearty soup in response to questions other correspondents posed. He encouraged people to organize letter showers to celebrate birthdays and anniversaries. He saw the silver lining in the dark clouds of white slavery, world war, and demon rum. He believed that with knowledge people would do the right thing. So, Feyma tried to provide that knowledge, in the newspaper and elsewhere.

When Feyma reported on his visits to the county fair, not every Volksvriend correspondent shared his enthusiasm. The

37. Ibid., 1/31/1907, 1/27/1921, 4/29/1915, 8/25/1921, 2/7/1924. Feyma seemed fascinated by macabre deaths. He wrote a lengthy account of Maynard Larson's death. This 15-year-old from Sandstone was overcome by fumes while he was using a bucket to empty the oil lying in the bottom of a tank car. The car, with Maynard inside, was attached to a southbound freight train. The body was finally retrieved a week later in the Omaha freight yards. Ibid., 10/13/1921. 
Archer, Iowa, reporter contended that a fair was no place for a decent Christian to be. Feyma responded that American fairs should not be confused with their Dutch counterparts. There the beggars and minstrels, plus public drunkenness, made fairs "much too bad to frequent." But in the United States fairs provided a day for wholesome relaxation, a forum in which Christian tracts and lectures could uplift the community. Rather than standing on the outside condemning fairs, Christians should frequent these spaces to redeem the fairs from evil. Christians could see the goodness of God in the exhibits of produce and animals and in the handwork women placed on display. They also provide opportunities for women's groups to raise funds. ${ }^{3}$

When the weather turned foul, Feyma saw the good in distress. A snowstorm in late February 1922 left Sandstone marooned for two days without train service and mail delivery. The roads were blocked by 12-foot drifts. Feyma had not seen anything this bad in all of his years in Minnesota. There were reports of families without food. And yet... God had sent the storm to provide work for the unemployed "so that young and old, men and women, anyone capable of wielding a shovel could help with the cleanup and work for more than a week. And there is still more work remaining. Also right here in the railroad yards. Thus this snowstorm was a great blessing.." ${ }^{39}$

World War I inspired visions of the apocalypse in Feyma's mind long before two of his sons were called to arms and one of them died from influenza in a French field hospital. Before the United States entered the war, when De Volksvriend's correspondent from Winnipeg, Manitoba, reported on a growing labor shortage in Canada, Feyma remarked that of course there were fewer workers because no one would move to "that much ballyhooed place" lest they be drafted to serve in the "death trap" of Europe. "Pity the parents of Canada!" The previous year Feyma had reported on the return of Dutch Americans from Pine County who had gone to Canada as homesteaders, only to abandon their claims rather than face military service. Feyma wondered if strange new birds roosting in the nearby groves

38. Ibid., $9 / 23 / 1920,10 / 14 / 1920$.

39. Ibid., 3/9/1922. 
were also refugees from the war in Europe. "People cannot always pay for passage to this land; but the birds have a free ticket" in the rigging of ships. ${ }^{40}$ How they then came to Minnesota, he did not speculate.

When the United States joined the war effort in April 1917, Feyma first noticed the change when soldiers appeared in Sandstone to guard the railroad bridge over the Kettle River a mile north of town. Soon afterward the local home guard unit (90 men strong), armed with searchlights for the night watch, took over minding this vital installation on behalf of the nation's defense. When three local boys left to be inducted into the navy, only to have two of them rejected, Feyma mused, "I thought they were all fit to be sailors, but apparently they are selective." He also thought the launching of motor boats on a nearby lake preferable to launching submarines. He referred to local draftees as having received "an unlucky number." Sandstone organized school girls into a knitting circle that made sweaters for soldiers. In this Feyma saw something both "commendable . . . and educational." Yet his last comment was the unwarlike statement, "And let us beg the Lord for peace." ${ }^{41}$

The aftermath of the war - the toll of dead soldiers, the six million deaths from influenza - convinced Feyma that he was living in a 120-year period that presaged the Second Coming. He compared this to the 120 years God had given Noah's contemporaries to repent before the Flood. Feyma published an elaborate comparison between Noah's Ark and the Titanic, likening the ill-fated ship to an idol. "The Ark was God's rescue ship. The Titanic was humanity's funeral boat."42 But underlying these gloomy thoughts was his belief that divine intervention would make the world a better place in the end.

Meanwhile, virtuous Christians needed to fight the good fight against vice, particularly white slavery, liquor, and tobacco. The latter was an unusual stance among Dutch Americans, given the prevalence of cigar use among men. But Feyma related the story of Jan and Max, a Hollander and a German.

40. Ibid., 10/28/1915, 9/10/1914, 12/24/1914, 2/4/1915.

41. Ibid., 4/12/1917, 5/10/1917, 8/9/1917, 12/20/1917.

42. Ibid., 3/25/1920. 
As they sat on a couch enjoying cigarettes together, they set the couch on fire. They took it outside to extinguish the flames, but the wind only intensified the blaze. "Know about cigarettes ahead of time; they are dangerous in every way, for fire and health. ${ }^{\prime 43}$ White slavery provoked Feyma's wrath as well. The women forced into prostitution were "like our sisters." The cure for this social ill was active concern. "Our Dutch people should be more aware of this so that some good may come of it." ${ }^{44}$

For many years prohibition remained Feyma's chief social improvement passion. As so many temperance advocates did, he often employed moralistic tales of lives ruined by drink. He believed that war in Europe made prohibition even more necessary, because "drink kills more men than bullets, and sends them to damnation, and makes wives and children ashamed." He told of liquor being transported into Sandstone by automobile and of drunks lying on the streets of town. He exulted in the success of an undercover agent who located a blind pig (a speakeasy) in town. ${ }^{45}$

When Sandstone was poised to pass a local option ordinance, Feyma's optimism rang out: "Many of our housewives are praying for God's blessing to rest on this endeavor." When the local voters opted to close the saloons, he sang, "Now on Saturday morning the mothers will be able to use the pay the workers received at the quarry for afternoon shopping, instead of the fathers taking the check and wasting it at night with the men who turn paper into gold." In his New Year's greeting for 1914, Feyma wished that all "would strive for the coming of God's kingdom, hope that what the angels sang in Bethlehem

43. Ibid., 2/23/1922. On cigar use among Dutch Americans, see Robert P. Swierenga, Dutch Chicago: A History of the Hollanders in the Windy City (Grand Rapids, MI, 2003), 23, 310, 491, 508, 584, 700. Samuel Gompers, the founder of the American Federation of Labor, was a cigar maker by trade and Dutch by ethnic background. Van Hinte, Netherlanders, 615.

44. De Volksvriend, 6/5/1913, 2/16/1914. Feyma's comments fit well into the rhetoric of the social reform movement that opposed white slavery. David J. Pivar, Purity Crusade: Sexual Morality and Social Control, 1868-1900 (Westport, CT, 1973); Brian Donovan, White Slave Crusades: Race, Gender, and Anti-Vice Activism, 1887-1917 (Urbana and Chicago, 2006). I am indebted to my colleague Dr. Kristin Kobes Du Mez for this insight.

45. De Volksvriend, 11/7/1918, 6/23/1914, 9/21/1916. 
FIGURE 3

Frequency of Articles Written by Klaas Feyma in De Volksvriend

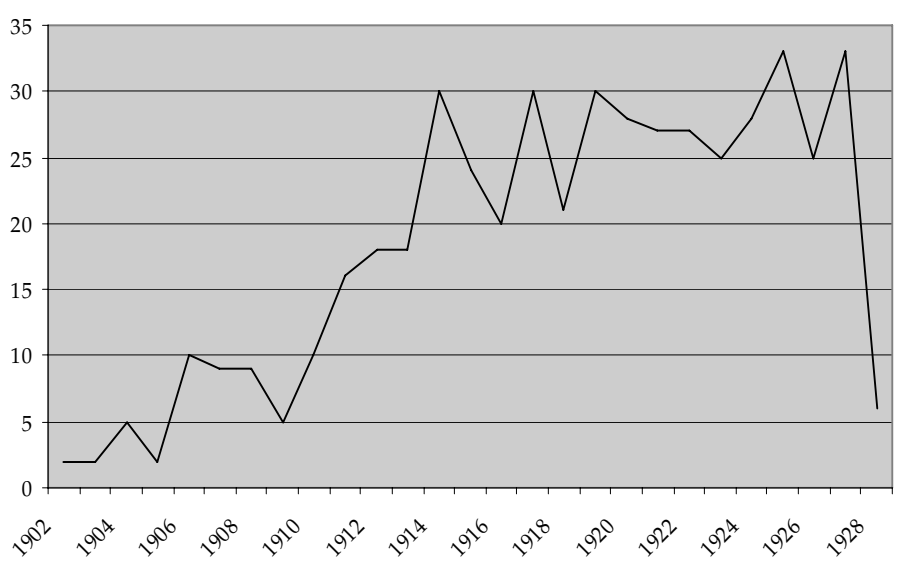

will not be forgotten, and that all, both young and old, would work to close the saloons." To punctuate his belief, a few months later he related that "an acquaintance of mine was a well-respected man five years ago and had a good business. Now he is poor, losing everything down his throat." Feyma enthused about a water bottling plant as a stimulus for the local economy, while loathing the use of alcohol as a pain reliever for dying soldiers. He compared the remedy to "giving a horse a whipping to make it better." When prohibition became the law of the land in January 1920, he joined the celebration at the Sandstone Temperance Hall for "the funeral of John Barleycorn." ${ }^{46}$

Correspondents such as Klaas Gerben Feyma were the heart and soul of the correspondence features in De Volksvriend. In 28 years the heading "Sandstone, Minnesota" appeared 493 times before the "faithful correspondent" finally succumbed. His contributions grew with his age as increasing leisure afforded him the time to write more and more (fig. 3). Curiously, the more he wrote the more he and his Dutch American neighbors saw themselves as Minnesotans and Americans. Over the years even his sense of Calvinist superiority faded as he became acquainted with Swedish Baptists, German Lutherans, and Scots Presbyterians in his adopted town. His cultural borders expanded to en- 
compass the likes of evangelists such as Billy Sunday and Aimee Semple McPherson. We know all this because he reported his observations in a weekly newspaper that was aimed at Dutch-speaking Americans like himself.

ABOUT THE TIME that Feyma was chatting with writers in California and Texas, De Volksvriend reached its peak circulation of about 6,000. By 1931 the number of correspondence articles peaked at an average of 55 per week; 115 correspondents from 17 states and one Canadian province wrote in during the first four months of that year. A new editor, Rev. B. D. Dykstra, who would control the paper's content during much of its remaining two decades, had no doubt that his work served as "the cement that would continue to hold the Dutch people of the middle west together and heighten their ethnic consciousness." ${ }^{48}$

Not every observer completely understood such enthusiasm, or such arcane messages. The bemused Dutch writer Jacob Van Hinte summarized the correspondence columns this way: "Even the smallest happenings are reported; thus it was learned by the Hollanders in the farthest West as well as in the farthest East of the United States that in Leota, Minnesota, 'little Harriet Hofkamp celebrated her ninth birthday with her little friends. The mother had provided for delicious refreshments, and the children had a pleasant afternoon.' " But Van Hinte did understand that a Leota birthday party notice helped to place Dutch Americans in a larger context. In words that foreshadowed the influential works of theorists such as Benedict Anderson and Jürgen Habermas, Van Hinte observed, "By keeping abreast of other Hollanders' activities, they [Dutch Americans] constitute, so to speak, one gigantic family from the Atlantic to the Pacific Ocean, from Mexico to far beyond the borders of Canada ... [and these papers] especially De Volksvriend reached out over an enormous territory - several times the size of Europe!" ${ }^{\prime 9}$

47. Ibid., 1/21/1926.

48. Dykstra, "B.D.," 121-22.

49. Van Hinte, Netherlanders, 924. (This edition of Van Hinte's book includes an illustration of De Volksvriend, complete with a healthy dose of "Correspondence" located on page one. Not content to rely on such correspondence, however, Van Hinte traveled across the United States visiting Dutch colonies in prepara- 
Over time, the number of correspondence articles began to decline, as did the number of locations from which they came. Most telling, however, was the drastic drop in articles from northwestern Iowa (fig. 2). In its first decades, De Volksvriend attracted advertisers from Iowa and beyond. Booksellers, land dealers, and patent medicine companies - from J. B. Hulst and Eerdmans-Sevensma in Grand Rapids to Theodore F. Koch in St. Paul and R. E. Werkman in Seattle and to a patent medicine called Dr. Piet's Zokoro manufactured in Chicago — all provided the revenue that kept the newspaper viable for many years. But the onset of the Great Depression and the declining purchasing power of an aging readership led advertisers to spend their money elsewhere. Sioux County's commissioners no longer saw the need to print notices in Dutch. By 1941 virtually all the paper's advertising came from businesses in and around the immediate Orange City area. And by then the advertisements were invariably in English even though the editorial content was still in Dutch.

The stark divergence between a growing dependence on local advertisers and a declining local interest in the newspapers' content doomed De Volksvriend. During the final declining years, a dwindling cadre of correspondents continued to faithfully report on their communities. But readers in Bellflower, California, or Lynden, Washington, would never buy an Oldsmobile from Cambier Motors in Orange City. That realization drove the publisher to inform editor B. D. Dykstra during the fall of 1951 that the paper would cease publication at the end of the year.

HENRY HOSPERS, Henry Oggel, and B. D. Dykstra may have been the people who assembled De Volksvriend for more than 75 years, but in a real sense De Volksvriend was people like Klaas Feyma. They read it and they wrote it. They thought with good reason that thousands of like-minded and like-speaking people really cared about things like Minnesota birthday parties or suc-

tion for writing his monumental survey of the Dutch ethnic settlements in the United States.) Cf. Anderson, Communities; Jürgen Habermas, The Structural Transformation of the Public Sphere: An Inquiry into a Category of Bourgeois Society, trans. Thomas Burger (Cambridge, MA, 1989). 
cessful Christian school pie auctions in South Dakota. Together they would speculate on whether bachelors bidding up a luscious lemon meringue were motivated by the desire to support a worthy cause or to impress the eligible schoolteacher that they were financially able to support a wife. Such things formed the foundation of the imagined community De Volksvriend created among often isolated Dutch American enclaves.

People who often had lived side by side, either in the Netherlands or in the United States, could remain "neighbors" in each weekly edition of this newspaper. Or they became neighbors for the first time through its pages. De Volksvriend kept them informed of the activities of their compatriots across the continent and back "home" in Europe. The editors who solicited these submissions and devoted up to one-third of their column inches to printing them also commented on them. From Klaas Feyma, and more than a hundred other writers, the editors gained a sense of what was important to Dutch Americans. The editors provided a space, a sphere, in which Feyma and his colleagues conversed with each other and together learned what America was about and how they could ease themselves into its cultural patterns. This was part of the process by which Hollanders evolved from immigrants to hyphenated Americans to Americans with the hyphen either erased or fading.

For an hour or so each week the readers of Orange City's Dutch-language newspaper were able to transcend the physical limitations that kept Dutch Americans apart from one another and mimic in print the gatherings they had once known and the conversations they had once enjoyed when they lived in other places in another time. In the now microfilmed pages of De Volksvriend we see a hint of the world Klaas Feyma and his fellow correspondents knew and loved in America. 